JACEK SZOŁTYSEK

\title{
Senior-friendly urban information system - identification of a problem
}

Prof. UE Ph.D., Eng. Jacek Szołtysek University of Economics in Katowice, Department of Social Logistics

\section{Introductory remarks}

Author's considerations stem from a conflict between the whole urban community and seniors that is observed in contemporary cities. Anglo-Saxon researchers - Ch. Book, G. Mooney and S. Pile - believe that the conflict in question is a permanent situation that affects social and spatial manifestations of the city structure. What is more, as a result of conflicts and co-operation that results from such conflicts a city is organised and used by different social groups. When a city structure is analysed in more detail, it is possible to see that some elements complement each other but there are also some opposites. A city structure often consists of different worlds that do not overlap although they function in a parallel manner (Kotus, 2005, p. 15). Researchers highlight that while undertaking actions that are supposed to increase effectiveness of city management, it is really important to pay attention to social conflicts that refer to spatial - urban economy (Stawasz, 2005, p. 17). Depending on literature taken into consideration, one can encounter different notions like 'spatial conflict', social conflict in the spatial context' or 'social conflict in 
the quest for space'. Society and space enter into different relations including shaping space. Shaping space may be performed through providing space with new shapes and functions or by means of some behaviours observed within the very space. Processes of shaping space may be meticulously planned although they also might take a more spontaneous form, thus generating unintended effects. Well-considered creation of physical framework for social life in a given territory in compliance with already established rules of behaviour is called spatial planning (Miazga, 2001, p. 6). Since complexity and diversity of urban organisms are still increasing, there is some need to update ideas related to cities and processes that are observed there (Kotus, 2005, p. 13). Issues that are discussed in this article refer to adjusting city space to needs of the elderly and they are quite new in the context of implementation of adjustment activities. There are no complex solutions that as a result of synergy between individual aspirations could also meet new developmental needs of cities (Nowakowski, 2004, pp. 136-137).

\section{Backdrop for discussions}

The fact city population is ageing is not only a foregone conclusion, but it also sparks questions about place of seniors within the society. When more than $7 \%$ of population becomes 65 years old, the society is classified as old. This pertains to Poland as well - already back in $199510 \%$ of society was 65 or over. Today, that number has gone up to $16 \%$, third of which are people over 75 years old. Those numbers will only grow. In 2035 Poland is forecasted to have $23.2 \%$ elderly, however, cities will see those numbers higher (24.3) than rural areas (21.7). Through the period covered by that projection, the percentage of elders living in cities is going to be higher than in the country. Expected to be even more spectacular are changes in age group 80 and over, which between 2010 and 2035 is going to more than double in size - from 3.5 to 7.2 . In 2010 it was 3.4 in cities and 3.6 in the country. It is expected that by 2035, percentage of that age group in cities will have more than doubled to $8.1 \%$, whereas in rural areas, where demographic ageing started earlier, will have grown to 5.8\% (Central Statistical Office, 2009). That means that from demographic point of view, the group of elderly city users will have increased in sized. At the same time, this positive from vantage point of society process needs to be looked at from demographic structure of city residents. Not only does the number of seniors grow - more and more people are in retirement age - but also the number of working age people decreases. The support ratio (defined as no of people age 15-64 per 1 pensioner 
age 65+) will decline from 12 (in the 50's of the XX century) to 3 in 2035. This situation entails radical economic consequences. The fallout will engulf social benefits system and will have social consequences (Jozwiak 2012, p.71), which could prove even worse. Age distribution of people between 15 and 64 years old changes in a negative way particularly due to low birth rate, which between 2000 and 2010 oscillated between 1.3 and 1.5. Should the birth rate continue to stay at 1.5 for a prolonged period of time, it will cause difficult to reverse consequences. (Jozwiak 2012, p. 72-73). As far as city citizens are concerned, the birth rate is even lower than for the total population (Okólski, Fihel, 2008).

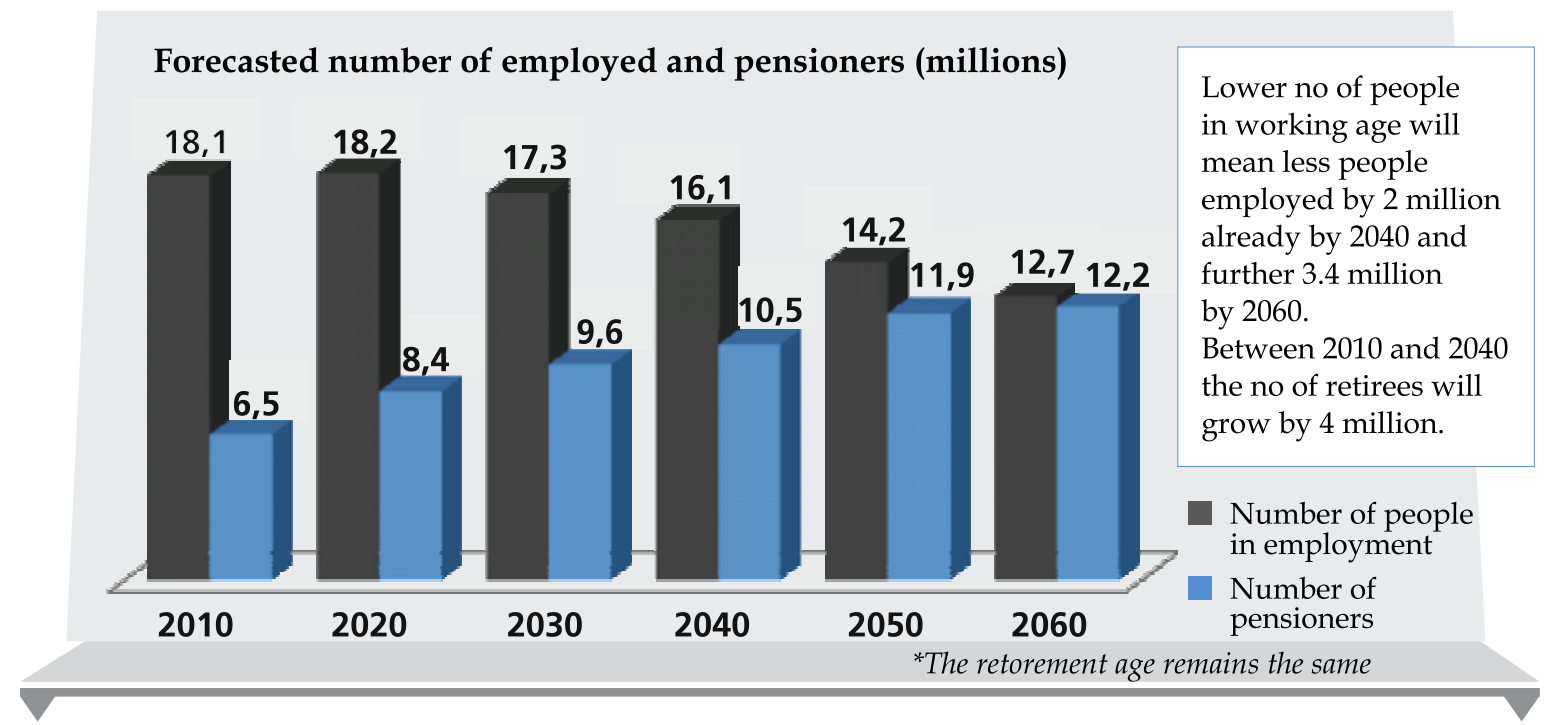

Figure 1 Forecasted working population and retirees (millions)

Source: Speech by Michal Boni the Minister of Administration and Digitization on behalf of the President of the Council of Ministers Donald Tusk, in: „Polska w Europie - Przyszłość demograficzna” (edit. Z. Strzelecki, A. Potrykowska, Tom I, Warszawa 2012, p. 40)

As per figure 1 forecasts, the working population to unemployed is going to equalise in about 50 years. It also indicates the role of seniors within the society is going to change in that time.

\section{Senior and its role in the society}

Image of old age has been changing through time and the dualism of attitudes spread across ages and cultures. In the olden days, there were not many elders 
who would reach an advanced aged. Seniors were respected and held in high regard - in the society they would normally play the role of wise men, judges or priests. Their opinion was an important one. If they went down with a sickness, they would be attended to. Pejorative image of the oldest generation held for years, changes from perspective of the seniors themselves. The elders have an altogether different perception about the old age. According to seniors, and image of and attitude towards elderliness is determined by: education, profession in working years, marital status, past and current health conditions, level of income, family relationships and friends (Posluszna 2012, p.76). Despite stereotypes and prejudice in Polish society towards the elders, they themselves are far from feeling excluded from the social life. On the contrary, old age means more time to spend with their friends and acquaintances and greater involvement with their families. Thereby the family, but above all the role of grandparents becomes their priority. The way they help their adult children is by taking care of grandchildren, the household and giving financial support, what makes them feel a sense of purpose and being accepted. Seniors feel obliged to support their children. By doing so, they feel satisfaction and sensation of pleasure (Leszczynska - Rejchert 2005, p. 5). Moreover, their financial independence gives them a strong position in the family and induces their relatives to pay due respect and keep partner relations (Tarnowska 2005, p. 8). On the other end of the scale are singles. That lifestyle becomes ever more a tendency particularly preferred by city dwellers. The number of young people confining themselves to the life of "single" is on the rise. Among a plethora of reasons the most critical are fast pace of life in big cities, where the majority of youth and adulthood is spent working, and people are robbed of their private life due to professional engagements and lack of time. Being a single is a phenomenon, which is driven by fashion, shift in priorities and propaganda of independence (particularly due to feminist ideology) or any potential benefits (the most referred to is "freedom") (Szymanowska 2009, p. 63-74). Reasons for loneliness among seniors are plentiful - from death of the closest ones to solitude through sickness, both physical and mental. An important group of factors is social exclusion. Social marginalisation of the elderly is usually caused by a general perception that age group could not serve any purpose in the society. That image is mainly created by: inability to adopt fast paces of life and accommodate changing environment, consequent mental and cultural changes, change in language (new words, terminology, often loanwords from English) and ubiquitous technology. Seniors are often baffled by the "noise of all the new information" and find it hard to take it all 
in (Dąbrowska 2011, p. 87). They lose track of principles (or are no longer valid) putting events and facts in logical order. Subsequently elders are losing their sense of belonging in the world, but above all, they lose their identity both from the outside world perspective and their own (Seredynska 2011, p. 140). There is still a need to understand older people's various requirements in their use of space, reflecting their diversity and different backgrounds. While some are experienced travellers who are used to finding their way in unfamiliar spaces, others may suffer cognitive impairment, which makes previously familiar areas unrecognisable and means they need different cues in their environment. Treating 'age' as a single category can therefore be unhelpful for planners in designing urban spaces concludes the research.

\section{The city, its policy and seniors}

Modern city is no longer an urban space serving purpose of living space for its residents. It is also a space where experiences are created, encountered and gained - centrepiece for today's cultural awareness (Gutowski 2006, p.3). With regards to the spatial thread, the following definition is worth quoting: "The city is a collective space belonging to all who live in it. These have the right to conditions which allow their own political, social and ecological development but at the same time accepting a commitment to solidarity" (The European Charter). Urban space is in essence a public space, which belongs to everyone, but at the same time, to nobody. That definition refers to space as urban places catering for fundamental needs of its citizens. Those needs are not homogeneous, even within particular urban groups of society. City management should be based on profound knowledge about them. The city is a battle ground where interests (vested interests) of various groups - city space users meet, clash and coincide. Those groups achieve their goals by using resources available to them within the urban space (Jałowiecki 1988). Different resources have different characteristics thus present different values depending on users. The same resources, based on individual preference, are going to be perceived differently (Grochowski 2005, p.75). Resources availability is achieved through managing the city. Management is a form of influencing humans where they are convinced to complete particular tasks and use organisational resources to achieve planned goals (Markowski 1999). City management is also identified as implementing concrete policies (Peski 1999) and perceived as actions undertaken by local government to produce desired outcome of processes and phenomena taking place within the urban space (Kosiedowski 2001). Hence, not only setting out policies is important for 
city users, but also predominantly to make it consistent with needs, desires and requirements of city users. It might seem idealistic and unrealistic striving to provide for needs of all in line with social equality, so since it is acceptable to satisfy those needs partially, it is unacceptable to prioritise any groups over other. The underlying premise of local policy is its sense of community.

Urban policy is an activity planned by local government, set out and executed in collaboration with entities achieving their goals and satisfying their needs within the city. It should clearly state which objectives it intends to accomplish using that measures and justify that from the viewpoint of rationality and efficiency. Urban policy is aligned with goals of the governments responsible for that policy. It goes without saying, its goals go beyond what is beneficial for the city as an administrative unit. They are a function of ideological decisions and power struggles between groups of interest (Antoszewski, Herbut 1998). Local government is going to follow a policy most likely to keep it at the helm. It means seeking and striving for compromises and solutions, which would avert antagonisms and conflicts (Chmaj, Zmigrodzki 2001). This very common backdrop to decision making is precipitated by the intention to either keep or takeover the power by designing strategies and plans for developing in specific direction. Vested interests of individual groups in contention for power is an essential factor, however, not absolutely indispensable (Regulski 2002) In modern Polish cities, the elderly are not the age group most likely to be given any privileges, or even acknowledgement of their needs. Because they have little influence on local government (weak social position and vulnerability to manipulation) it is overlooked in development projects and urban policies. Establishing senior councils, often strongly opposed by other group of interest, in practice only makes more legitimate to forsake measures designed for the elderly. Seniors lack courage and determination to actively oppose the status quo where their interests are being side-lined. Furthermore, in light of current stereotypes, they reflect little of the development opportunities sought in young, educated professionals. "City officials are obliged to respect the dignity and assure quality living standards for all city residents by using all means available". (The European Charter) This recommendation of „The European Charter for the Safeguarding of Human Right in the City" should be the underlying premise behind designing urban policies, intended to cater for needs of all, including the most vulnerable - seniors. The elderly should be able to enjoy the autumn of their lives in full health, with a sense of security, by actively participating in economic, cultural, social and political life. In all fairness, however, the diversity of older people and their different needs are not fully recognised. 


\section{Urban space and needs of senior people - informational aspect}

An important value of city space has to be its ability to facilitate social communication based on direct, face-to-face human interaction. Cities create new spaces that are (or rather should be) based on measures for mobility, both in individual and social dimension. The city is a meeting place, and so needs to design and developed to create opportunities for establishing different relationships. It is necessary to create personal and social spaces, which go on to become a place of dialogue (Gutowski 2006, p. 218). Depending on the quality of offered space, it may develop, intellectually and emotionally stimulate or be destructive, disrupting or even destroying social ties (Porębska2010, p. 156). Natural limitations, which bound seniors due to age and fitness, makes difficult for them to access infrastructure and urban resources. One hand, this is an effect of physical disability advancing with age, thus creating an increasing number of invalids, mostly in the oldest age groups, on the other - inaction and passiveness of city council, which fails to facilitate access to city space for the elderly. This state of affairs determines the lifestyle of seniors. As far as mobility of Polish seniors is concerned, their ability to cover space has been on the rise for the past decade, and in the years to come, it should be expected to grow further. This is a consequence of increasing number of people actively driving vehicles, who have certain habits and prefer to travel in a particular way. No regulation in place which would limit the right to drive mechanical vehicles for elderly could create many problems, however, putting abruptly end to independent mobility by removing right for driving cars would raise an additional, difficult to surmount barrier. Driving cessation is connected to reduced quality of life, reduced out-of-home activity and life satisfaction and is also a strong predictor of worsening depressive symptoms. Car use is crucial for those with waning physical strength and sensory abilities to meet the demands of everyday life and for maintaining their participation in social and cultural activities. The reasons why many older people give up driving appear to be the same reasons why they avoid using buses. The inability to drive or use public transport leaves older people with little option other than to travel by car as passengers if and when the opportunity becomes available (Vine, Buys, Aird 2012, p. 424).

The issue of making the city space more senior-friendly, is also related to navigating within that space. Elderly people gradually lose the sense of spatial awareness, cognition and understanding of signals coming from surrounding environment is impeded (disrupted). Against common stereotypes, however, seniors are not that much dependent on others. The latest research shows that 
the percentage of people between 65 and 69 years old who think are in need of a carer person is $5.5 \%$. The same percentage for people at least 90 years old is as high as 50.3\% (Błędowski 2012, p. 449 -). Hence the issue of spatial planning accommodating needs of the elderly, including a purpose-built information system, is not any more a moral obligation, but a tangible necessity. By urban information system, the author means all external information in form of signs: visual (graphical, light) and sound, which facilitate navigating through space, and interactive systems addressing message recipient in order to help make a decision about travel direction. Said system in closely linked to all modes of transport in the city as well as the term of walkability, defined as: the extent to which the built environment supports and encourages walking by providing for pedestrian comfort and safety, connecting people with varied destinations within a reasonable amount of time and effort, and offering visual interest in journeys throughout the network (Southworth 2005, p. 248). Unfortunately, in Poland the most apparent errors in spatial planning include overseeing mobility of the elderly. Especially beyond metropolitan areas, where that issue is not so much of a nuisance. We should take the example of good practices e.g. markings comprehensible for seniors. The OPUS project (Economics and Social Research Council) was intended to investigate how elders navigate through space as both pedestrians and public transport users. "Older people are increasingly experiencing unfamiliar places through travel. Creating spaces that make the urban environment more friendly and pleasant will be ever more important to enable older people to remain independent," comments lead researcher Professor Judith Phillips. "The OPUS findings have significance for planners in redesigning town centres, allowing them to develop inclusive environments that have meaning for older people (www. sciencedaily.com) Spatial awareness was analysed with relation to levels of stress caused by the task of reaching a particular destination (Carstens 1993). The research showed that: 1) Signs are of limited use even in unfamiliar new areas - they were often positioned incorrectly or too high, and 2) Designing outdoor spaces that are more easily navigable and walkable are important in making the environment less stressful and anxiety-inducing; 3) Buildings and landmarks are particularly important as navigational aids, especially churches. According to other research, seemingly insignificant information matters, such as material used to build pavements and shape of benches in the street. Older research showed that people (not necessarily senior) navigate through space using ground-level, in-sight parts of buildings, especially in urban agglomerations. Therefore, façades should have distinguishing features unique for that particular building. It would be 
foolhardy to expect spatial planning would be entirely determined by needs of the elderly, however, some aspects of how urban spaces are organised could be improved (Hoff 2012, p.113-114). The drawback of Polish cities is the abundance of road signs, e.g. in residential areas, whilst signs for pedestrians are scarce. In Germany, urban spaces are being cleared off excessive information, especially that caused by over-abundant road signs. In Poland, colours are used to an insufficient degree for facilitating intuitive recognition of landmarks (Hoff 2012 p. 114). Writings are unclear and confusing - both from perspective of colour scheme and wording, as well as size of the letter and positioning of the information itself. Signs on public transport stops, legibility of time tables and sings on public transport vehicles are also problematic for seniors. In the lineof-sight are located both critical and distracting information making it difficult to obtain right information - e.g. big, vivid adverts. Road surface marking on pedestrian crossings and pavements are worn out posing a substantial threat to elderly in the cities. The last argument pertains to sharing pavements for cyclists and pedestrians. Research of Australian seniors showed conflict between pedestrians and cyclists on shared pathways are highlighted as being factors that undermine the walkability of these systems. Places where vehicular transit systems and non-motorised user pathways merged are usually found to be particularly troublesome. Confusion about right of way protocol among motorists and pedestrians when they meet at zebra crossings is also cited as an issue in this same neighbourhood (Vine, Buys, Aird 2012, p. 434). Hence, clear marking of lanes is one of elements of information as to how a pavement should be shared. Similar situation applies to pedestrian crossings - it is recommended to design space around the crossing to make easy looking out for oncoming traffic. As far as traffic lights are concerned (apart from making green light periods longer), two lanes for pedestrian traffic should be designated (that way people going in opposite directions should not walk into each other). Furthermore, traffic lights should issue messages - e.g. the road is safe to cross or red light in 5 seconds. Very useful are timers which show what time has left for the light to change to red. Signposts giving directions for particular destinations in the city should be in light-of-sight and visible (view not obstructed by e.g. hedge). The same applies to street name places. They should be located is a thoughtful manner, making it easy for city users to navigate and finding their whereabouts. Public toilets, first aid spots, free phones for calling help should also receive due markings. Some clauses of planning and design regulation are given below as a case of the pedestrian-related development control in the city area (Yianzhou, Xiaojing 2009, p. 7): 
- for the car-dominant paths, clear signals should be placed at certain intersections to remind car drivers to pay attention to the pedestrian crossing; at the same time signals leading to the public transport station are also needed,

- for the pedestrian-first paths, the width of sidewalks should be wide enough, and the reduction of parking plots along the path should be considerable,

- for the full pedestrian paths, detailed landscape design is needed to improve the quality of pedestrian environment,

- for the pedestrian generation points (metro stations, bus stops), convenient pedestrian linkages should be provided,

- for the open space (ex. waterfront plaza), the connection with the pedestrian paths needs to be carefully designed, which is expected to provide more convenient access for the pedestrian to the waterfront area.

Modernisation of city space entails constant changes. That space is different in many dimensions. We talk of modernisation when unmodernised societies meet with modernised ones. Modernisation of a city changes its functional structure, land development, architecture and transportation system. Consequently, its entire image changes as do the people (Grochowski 2005, p. 83).

\section{Conclusions}

City space is evaluated by its different explorers - those permanent and occasional, i.e. its inhabitants, commuters or tourists. Since a contemporary city is an entity that tries to meet all needs of its inhabitants, it is necessary to point out that there are constant transformations of urban space (Mikielewic, 2007, p. 133-134). The city should serve to the benefit of all of its users - including the group neglected and discriminated by the local governments the most - seniors. To large extent, the above concerns equal access to infrastructure and resources by facilitating/enabling safe travel across the public space. Public space plays a crucial role in the quality of a city or an urban space, however the quality of life of a person depends on several factors. From a territorial, planning, and design aspect, outdoor public spaces must be definitely considered. In the meantime, a broader sense of - public space, that includes shops and services, residential areas and private or semi-private spaces, facilities such as clubs and meeting points for older people should be reinforced. This paper focused mostly on reasons justifying the need to undertake actions intended to improve the urban information system, making is easy and safe for seniors to use public space. In terms of cost, the bottom line of those measures is low financial outlays. 
A senior-friendly city is a city for everyone, a universal city that results from the human diversity that lives it and constitutes it. It is a networked city in which taking into account the more demanding target population can help creating favourable conditions to the majority of the population.

\section{Abstract}

\section{Senior-friendly urban information system - case study}

Increasing urban population, ageing and growing importance of the elderly - those are three independent trends which are currently observed in urban areas. Place of a senior person within society is changing. Overlapping with above trends is inefficient city management as a consequence of growing and denser city population in big agglomerations. It is a common practice that seniors are perceived as second-class citizens. This is reflected by city politics which overlooks measures facilitating day-to-day existence of the elderly in urban space to the benefit of younger generations. City council is allocated a predetermined budget to cater for needs of various age groups. Those resources should be split in a just way, equally between all citizen groups. The evidence the city governing body is doing just that is assurance of mobility to all groups - including seniors. Bearing in mind their health, fitness, access to infrastructure should be facilitated by customising urban information systems to fit perception of the elderly. This way city management shapes city space, thus providing the space in question with new functions, enabling new bahaviours within the framework of the space that has been available so far. Creating a new system of urban information is therefore a management related problem that has to be dealt with taking city related factors into consideration. Decision makers have to solve a conflict that is observed between different groups of interest.

Keywords: citymanagement, conflict of interest, seniors, system of urban information.

\section{Streszczenie}

System informacji miejskiej dostosowany do potrzeb seniorów - identyfikacja problemu

Współcześnie $\mathrm{w}$ miastach obserwujemy niezależnie trzy trendy

- zwiększania liczby ludności, starzenia się ludności oraz 
zwiększające się znaczenie grupy seniorów dla funkcjonowania miast. Zmienia się miejsce seniora w społeczności. Na te trendy nakłada się ponadto - obserwowana dla dużych miast - wraz ze wzrostem liczby mieszkańców - zmniejszająca się sprawność $\mathrm{w}$ zarządzaniu miastami. Miasta $\mathrm{w}$ swoich politykach traktują seniorów jak obywateli drugiej kategorii i w istocie pomijają te działania, które mogą ułatwić funkcjonowanie osób starszych w przestrzeni miasta, gdy konkurują one $\mathrm{z}$ działaniami na rzecz młodego pokolenia. Miasto dla realizacji celów różnych grup użytkowników oddaje do dyspozycji określone zasoby. Dostęp do tych zasobów powinien być sprawiedliwy i zapewniać zaspokajanie wszystkich potrzeb na zasadzie równości. Jednym z podstawowych wyznaczników takiego stanu jest zapewnienie mobilności dla wszystkich grup - w tym seniorów. Uwzględniając ich kondycję zdrowotną, dostęp do przestrzeni należy ułatwiać poprzez dostosowanie systemu informacji miejskiej do percepcji seniorów. W taki sposób zarządzanie miastem kształtuje przestrzeń miasta nadając jej nowe funkcje, umożliwiając nowe zachowania w ramach dotychczasowej przestrzeni. Tworzenie systemu informacji miejskiej jest zatem problemem zarządczym, realizowanym w uwarunkowaniach miasta, w którym zarządzający muszą rozwiązać konflikt jaki istnieje między poszczególnymi grupami interesów.

\section{Słowa}

kluczowe: zarządzanie miastem, konflikt interesów, seniorzy, system informacji miejskiej.

\section{References}

1. Antoszewski A., Herbut R. (1998) (edit.), Polityka w Polsce w latach 90. Wybrane problemy. Wydawnictwo Uniwersytetu Wrocławskiego, Wrocław.

2. Bledowski P. (2012), Potrzeby opiekuńcze osób starszych [in:] Aspekty medyczne, psychologiczne, socjologiczne i ekonomiczne starzenia się ludzi w Polsce, edit. M. Mossakowska, A. Więcka, P. Błędowski, Publisher Termedia, Poznań.

3. Carstens D. Y. (1993), Site planning and Design for the Elderly: Issues, Guidelines, and Alternatives, February. 
4. Central Statistical Office (2009), Prognoza ludności na lata 2008-2035, GUS, Warszawa.

5. Chmaj M., Zmigrodzki M. (2001), Wprowadzenie do teorii polityki. Wydawnictwo Uniwersytetu Marii Curie-Skłodowskiej, Lublin.

6. Dabrowska P. (2011), W trosce o życie, Fides et ratio, UKSW, Warsaw, 2(6).

7. Economic and Social Research Council, the biggest organisation of that type in United Kingdom.

8. Grochowski M. (2005), Polityka miejska a kształtowanie struktury przestrzennej miasta metropolitalnego (przypadek Warszawy), Prace i Studia Geograficzne, Volume 35, Warsaw.

9. Gutowski B. (2006), Przestrzeń marzycieli. Miasto jako projekt utopijny, Warsaw.

10. Hoff W. (2012), Planowanie przestrzenne a potrzeby seniorów, [in:] Strategie działania w starzejącym się społeczeństwie. Tezy i rekomendacje, Rzecznik Praw Obywatelskich, Warsaw.

11. Jałowiecki B. (1988), Społeczne wytwarzanie przestrzeni, Książka i Wiedza, Warsaw.

12. Jozwiak J. (2012), Czy w świetle badań naukowych możliwa jest odnowa demograficzna Polski w: „Polska w Europie - Przyszłość demograficzna”, edit. Z. Strzelecki, A. Potrykowska, Tom I, Warszawa.

13. Kosiedowski W. (2001) (edit.), Zarządzanie rozwojem regionalnym i lokalnym. Problemy teorii i praktyki. Wydawnictwo Naukowe Organizacji i Kierownictwa „Dom Organizatora”, Torun.

14. Kotus J. (2005), Społeczne dylematy w przestrzeni miejskiej, Bogucki Wydawnictwo Naukowe, Poznań.

15. Leszczynska-Rajchert A. (2005), Człowiek starszy i jego wspomaganie w stronę pedagogiki starości, Wydawnictwo UWM, Olsztyn.

16. Markowski T. (1999), Zarządzanie rozwojem miast, PWN Warsaw.

17. Miazga M. (2001), Społeczne problemy ksztattowania przestrzeni: przykłady studiów $i$ badań na rzecz planowania $i$ zarządzania przestrzenia $w$ różnych skalach, IGPiK, Warszawa.

18. Mikielewicz R. (2007), Defragmentacja miasta - "wydajność" przestrzeni miejskiej a jej percepcja, Czasopismo Techniczne, z. 1. Architektura z. 1-A, Wydawnictwo Politechniki Krakowskiej, Kraków.

19. Nowakowski T. (2004) (edit.), Logistyka a infrastruktura miejska. I Konferencja Naukowo-Techniczna. Wrocław, 7-8 października 2004 r., Wrocław.

20. Okólski M., Fihel A. (2008), Bilans demograficzny Polski w roku 2033: Ekspertyzy do koncepcji przestrzennego zagospodarowania kraju 20082033, Tom IV, Warszawa: Ministerstwo Rozwoju Regionalnego.

21. Peski W. (1999), Zarządzanie zrównoważonym rozwojem miast, Arkady, Warsaw. 
22. Porebska M. (2010), O potrzebie piękna w przestrzeni publicznej miasta, Architektura. Czasopismo Techniczne, Wydawnictwo Politechniki Krakowskiej, Issue 6.

23. Posluszna M. (2012), Aktywność rodzinna i społeczna osób starszych, Nowiny Lekarskie.

24. Regulski J., Polski samorząd po dziesięciu latach. [in]: S. Michałowski (2002) (edit.) Samorząd terytorialny III Rzeczypospolitej. Dziesięć lat doświadczeń, Wydawnictwo Uniwersytetu Marii Curie-Skłodowskiej, Lublin.

25. Seredynska D. (2011), Rodzina jako kontekst rozwoju seniora, UKW Bydgoszcz.

26. Southworth M. (2005), Designing the walkable city, Journal of Urban Planning and Development, 131, p. 248.

27. Szymanowska A. (2009), Kim są single - psychologiczna charakterystyka osób samotnie żyjących (in:) Diagnostyka i rozwiązywanie problemów psychologicznych dzieci i młodzieży, pod red. B. Kołdan, J. Kahlan, A. Fidelys, Sandomierz, Warsaw.

28. Tarnowska E. (2005), Stary człowiek w Polsce, Więź.

29. The European Charter for the Safeguarding of Human Rights in the City part. I.

30. Vine D., Buys L., Aird R. (2012), Experience of Neighbourhood Walkability Among Older Australians Living in Highh Density Inner-City Areas, Planning Theory and Practice, Vol. 13, No 3, September.

31. http://www.sciencedaily.com/releases/2010/12/101217091159.htm [07.06.2013].

32. Yianzhou T., Xiaojing Ch. (2009), Towards a walkable city: the planning practice of Shenzhen, China, 45th ISOCARB Congress. 